\title{
Arbuscular mycorrhizal fungi biodiversity: prospecting in Southern-Central zone of Chile. A review
}

\author{
C. G. Castillo ${ }^{1 *}$, F. Borie ${ }^{2}$, F. Oehl ${ }^{3,4}$, E. Sieverding 5 \\ ${ }^{1}$ Escuela de Agronomía, Facultad de Recursos Naturales, Núcleo de Investigación en Producción Alimentaria \\ (NIPA), Universidad Católica de Teтисо, Teтисо, Chile. \\ ${ }^{2}$ Center of Amelioration and Sustainability of Volcanic Soils, BIOREN-UFRO, Universidad de La Frontera, \\ Tетисо, Chile. \\ ${ }^{3}$ Federal Research Institute Agroscope, Institute for Sustainability Sciences, Plant-Soil-Interactions, Recken- \\ holztrasse 191, CH-8046, Zürich, Switzerland. \\ ${ }^{4}$ Departamento de Micologia, CCB, Universidade Federal de Pernambuco, Av. da Engenharia s/n, Cidade \\ Universitária, 50740-600, Recife, PE, Brazil. \\ ${ }_{5}^{5}$ University Hohenheim, Institute of Plant Production and Agroecology in the Tropics and Subtropics, Stutt- \\ gart, Germany.*Corresponding author: ccastill@uct.cl
}

\begin{abstract}
The main factors affecting the diversity of arbuscular mycorrhizal fungi (AMF) are host plant, environmental characteristics and geographical location. A better understanding of the influence of land use changes on AMF abundance will help in improving their management, leading to improved plant productivity in soils, and will also be useful in designing more sustainable agronomic management practices. The aim of this work was to document the occurrence and diversity of AMF species in the Southern Central zone of Chile. This information has been generated by seven separate studies which provide the basis for discussion of the AMF species found in this zone. The work includes a bibliographic review of the records from croplands, grasslands and forests generated by collections made during the period 2004-2014 in Chile. Overall we recorded 21 genera and 66 species of Glomeromycota. This represents $24 \%$ of species of AMF known so far. Acaulospora represents $23 \%$ of all species and Glomus 20\%. It is concluded that more studies are needed in this and other regions of Chile for a more comprehensive knowledge of the AMF diversity in the country. These biodiversity studies will help to define the ecology of these important soil microbiological resources.
\end{abstract}

Keywords: Glomeromycota, richness, Shannon-Wiener index, agro-ecosystem, taxonomy 


\section{Introduction}

Arbuscular mycorrhizal fungi (AMF) are thought to be the oldest group of organisms living in symbiosis with land plants (Redecker et al., 2000). AMF form a key functional group of soil biota that can contribute substantially to ecosystems sustainability and plant yields in crop production strategies (Urcoviche et al., 2014). They are beneficial for the whole plant community because they take up inorganic nutrients, e.g. phosphorus $(\mathrm{P})$ and nitrogen $(\mathrm{N})$, and water from the soil; and transport them to the colonized plant roots. In exchange their hosts offer protection and supply the AMF with photo-assimilates (Augé, 2001).

Abiotic factors (e.g. climate, edaphic properties), biotic factors (e.g. dominant vegetation type, interspecific interactions) and intrinsic properties of arbuscular mycorrhizal (AM) fungal species (e.g. dispersal capabilities, extinction rates) influence the abundance and distribution of AMF across multiple spatial scales (Chaudhary et al., 2014). Recent work examined the factors that influence Glomeromycota species distributions at global scales (Turrini and Giovannetti, 2012). Conventional spore-based investigations provide evidence that the distribution of AM fungal spores in soils can be affected by biotic and abiotic factors and soil disturbance regimes (Boddington and Dodd, 2000; Egerton-Warburton and Allen, 2000; Carvalho et al., 2003). Although the community structure of AMF can be inferred from spore communities, it should not be assumed that the AM fungal species inside plant roots, determined using DNA-based techniques, will exhibit the same patterns of occurrence as the spore communities in the surrounding soil (Liu et al., 2012).

The phenology of AMF may generate distinct root and spore communities, and this may help to partition fungal niches in space and time (Pringle and Bever, 2002).
Occurrence of certain AM fungal species has been related to soil $\mathrm{pH}, \mathrm{P}$ level, salinity, soil disturbance (Abbott and Robson, 1991), vegetation (Johnson et al., 1992), or the hydrological condition of the soil (Miller and Bever, 1999). In general terms, increase in soil $\mathrm{pH}$, nutrient status and salinity could result in a decrease of AM root colonization and spore density (Abbott and Robson, 1991). Despite the importance of AMF in the physiology and nutrition of plants, as well as in shaping plant communities, factors affecting the presence, diversity, spore density, and root colonization of AMF in soil are not well understood (van der Heijden et al., 2006). The main reason is the difficulty of establishing a causal relation between soil and plants factors and AM fungal populations (Vyas and Gupta, 2014). AMF can associate with a wide range of hosts present in the plant community, but the sporulation rates of AMF have been found to be host-dependent (Lugo and Cabello, 2002). Hostdependence of AM fungal populations may play an important role in the maintenance of AM fungal species diversity in grasslands (Bever et al., 1996), and suppression of mycorrhizal symbioses can decrease the dominance of certain plants in a natural ecosystem, thus increasing AMF species diversity (Hartnett and Wilson, 1999). Also, plant diversity may increase or decrease if the dominant plant competitors are weaker or stronger in mycotrophic terms than their neighbours (Hartnett and Wilson, 1999).

Studies conducted at the local scale have suggested that the taxonomic composition of AMF and the dominant AM fungal taxa colonizing plant roots may differ between habitat types, host plant species and locations in the root system (Wubet et al., 2004).

The easiest way to understand in which ecological conditions particular AMF species can be expected, is probably by studying the fungal diversity in different 
agro-ecosystems and relating their occurrence with soil characteristics, host plant communities, AMF fungal communities and climatic conditions. With such data available, the bio-geographical distribution can be superimposed, and the ecology of specific AMF can be identified.

\section{Glomeromycota phylum: taxonomy and classification}

The phylum Glomeromycota was established by Schüssler et al. (2001). The phylum is divided into three classes: Archaeosporomycetes, Glomeromycetes, and Paraglomeromycetes, with five orders: Glomerales, Diversisporales, Gigasporales, Archaeosporales, and Paraglomerales (Table 1a and 1b). Fifteen families, with 38 genera and about 270 species are known to date (Oehl et al., 2011a; 2015; Goto et al., 2012; Blaszkowski et al., 2013; 2015; Marinho et al., 2014; Silva et al., 2014; and the site http://www.agroscope.admin.ch/).

Table 1a. Taxa of Glomeromycota from class to genus level (Oehl et al., 2011a; Sieverding et al., 2014).

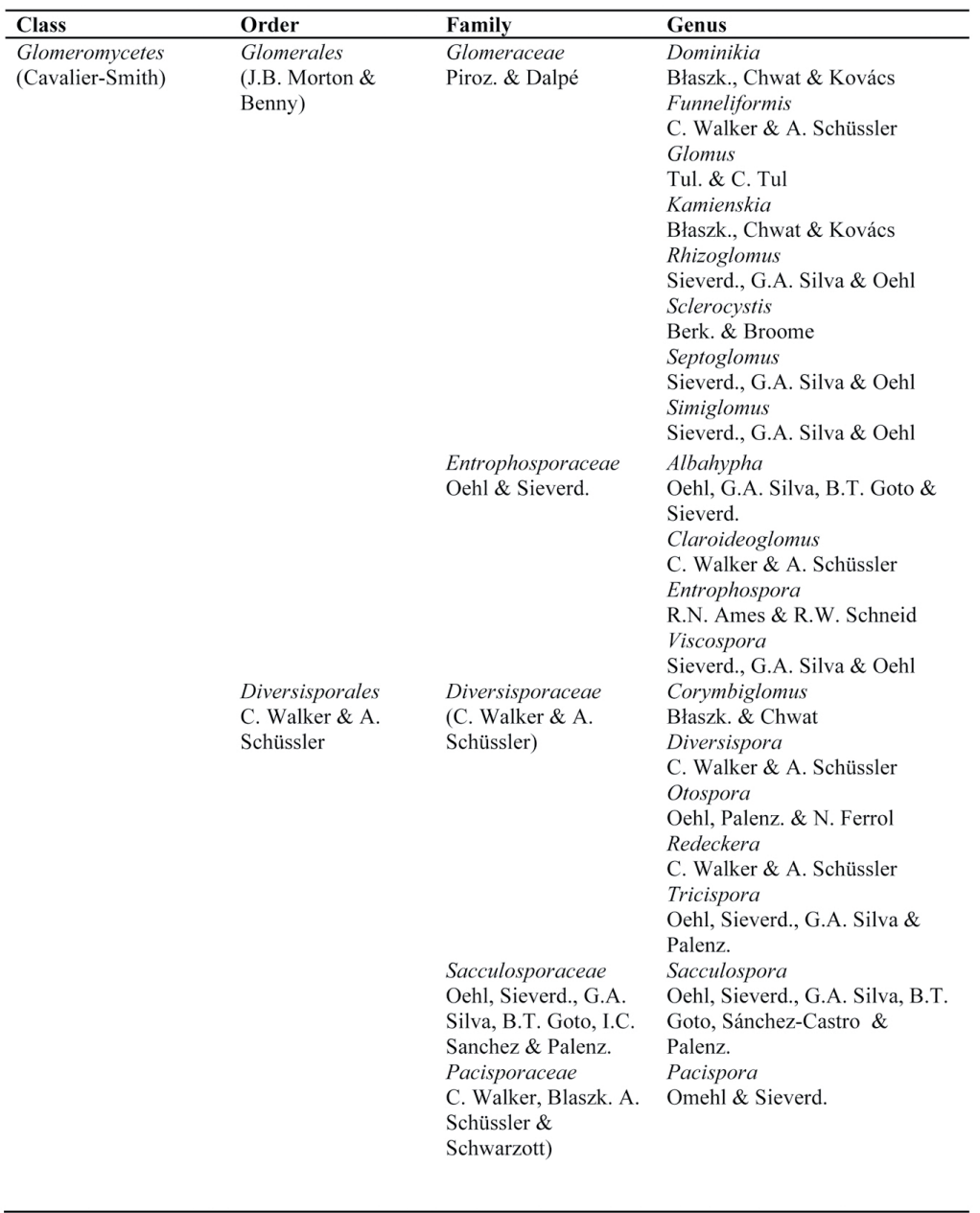


Table 1b. Taxa of Glomeromycota from class to genus level (Oehl et al., 2011a; Sieverding et al., 2014).

\begin{tabular}{|c|c|c|c|}
\hline & & Acaulosporaceae & Acaulospora \\
\hline & & J.B. Morton \& Benny & Sieverd., G.A. Silva, B.T. Goto \\
\hline & & & Kuklospora \\
\hline & & & Oehl \& Sieverd. \\
\hline & Gigasporales & Scutellosporaceae & Bulbospora \\
\hline & Sieverd., G.A. Silva, & Sieverd., F.A. Souza & Oehl \& G.A. Silva \\
\hline & B.T. Goto \& Oehl & $\&$ Oehl & Orbispora \\
\hline & & & Oehl, G.A. Silva \& D.K. Silva \\
\hline & & & Scutellospora \\
\hline & & & C. Walker \& F.E. Sanders \\
\hline & & Dentiscutataceae & Dentiscutata \\
\hline & & F.A. Souza, Oehl, & Sieverd., F.A. Souza, \& Oehl \\
\hline & & Sieverd. & Fuscutata \\
\hline & & & Oehl, F.A. Souza, L.C. Maia \& \\
\hline & & & Sieverd. \\
\hline & & & Quatunica \\
\hline & & & F.A. Souza, Oehl, Sieverd. \\
\hline & & Racocetraceae & Cetraspora \\
\hline & & Oehl, Sieverd. \& F.A. & Oehl, F.A. Souza \& Sieverd. \\
\hline & & Souza & Racocetra \\
\hline & & & Oehl, F.A. Souza \& Sieverd. \\
\hline & & Intraornatosporaceae & Intraornatospora \\
\hline & & B.T. Goto \& Oehl & B.T. Goto, Oehl \& G.A. Silva \\
\hline & & Paradentiscutataceae & Paradentiscutata \\
\hline & & B.T. Goto, Oehl \& & B.T. Goto, Oehl \& G.A. Silva \\
\hline & & $\begin{array}{l}\text { G.A. Silva } \\
\text { Gigasporaceae }\end{array}$ & Gigaspora \\
\hline & & J.B. Morton \& Benny & Gerd. \& Trappe \\
\hline Archaeosporomycetes & Archaeosporales & Ambisporaceae & Ambispora \\
\hline Sieverd., G:A. Silva, & C. Walker \& A. & C. Walker, Vestberg & C. Walker, Vestberg \& A. \\
\hline B.T. Goto \& Oehl & Schüssler & \& A. Schüssler & Schüssler \\
\hline & & Archaeosporaceae & Archaeospora \\
\hline & & J.B. Morton \& D. & J.B. Morton \& D. Redecker \\
\hline & & Redecker & Intraspora \\
\hline & & & Oehl \& Sieverd. \\
\hline & & & Palaeospora \\
\hline & & & Oehl, Palenz, Sánchez-Castro \& \\
\hline & & & G.A. Silva \\
\hline & & Geosiphonaceae & Geosiphon \\
\hline & & Engler \& E. Gilg. & F. Wettst. \\
\hline Paraglomeromycetes & Paraglomerales & Paraglomeraceae & Paraglomus \\
\hline Oehl, G.A. Silva, B.T. & C. Walker \& A. & J.B. Morton \& D. & J.B. Morton \& D. Redecker \\
\hline Goto \& Sieverd. & Schüssler & Redecker & \\
\hline
\end{tabular}

Table $1 \mathrm{a}$ and $1 \mathrm{~b}$ shows a schematic presentation of recently published taxa in the Glomeromycota phylum. According to Oehl et al. (2011), this classification was based on molecular (SSU, ITS, partial LSUrDNA, and partial b-tubuline gene) and morphological analyses (spore wall structures, structures of the spore bases and subtending hyphae, germination and germination shield structures).
Identification of AMF spores isolated directly from the field or from trap AMF cultures (e.g. Oehl et al., 2005) have been the main sources for the detection and identification of AMF (RobinsonBoyer et al., 2009). Since the first application of nuclear ribosomal gene sequencing to AMF spores (Simon et al., 1992), and root samples from the field (so-called environmental samples) (Helgason et al., 1998), molecular methods have become tools 
for studying the natural diversity of AMF (Öpik et al., 2014). However, naturally occurring AMF detected by molecular means still require identification, as the environmental sequences cannot be related to AMF species (Öpik et al., 2014).

\section{Arbuscular mycorrhizal fungal diversity}

Recording the occurrence of AMF populations in different ecosystems represents the first step toward understanding their functional diversity (Souza et al., 2010). This will enable the application of these species to be developed, particularly for the recovery of degraded soils. Intensive soil ploughing under the conventional cropping system negatively affects the AMF community, decreasing the number of species, and reducing the sustainability of this system when compared to non-tillage (Borie et al., 2006; Borrielo et al., 2012). All ecological studies indicate that the frequency of AMF species decreases with land use intensification (Oehl et al., 2003; Tchabi et al., 2008). This decrease in diversity is attributed to a complex selective pressure of agricultural practices, such as ploughing, fertilization and fungicide application (Roldán et al., 2007) and also may be related to the fact that the richness of plant species is reduced by increasing land use and increasing the P nutrient status of the soil. Besides agro-ecosystems, plant species, soil types, weeds, and previous crops also have an effect on the AMF population (Vestberg et al., 2005). Lower AMF species richness has been found in arable fields, while species-rich AMF communities were detected in different natural ecosystems and perennial communities such as tropical forest (Snoeck et $a l ., 2010)$. Studies from the tropics indicate that the AMF species richness in a monoculture like sugarcane grown in fertile soils (Colombian Mollisols) can be high (Sieverding, 1991). Information about species composition of AMF communities appears important in understanding mycorrhizal function in ecosystems (Johnson and Pfleger, 1992). Others authors, e.g. van der Heijden et al. (1998), have found that plant biodiversity, nutrient capture, and productivity in macrocosms increase significantly with an increase of AM hyphal length and AMF species richness.

Mycorrhizal fungi are of high value for ecosystem functioning and sustainability. More appropriate management of mycorrhizae in poor soils would allow a substantial reduction in the amount of minerals used without losses in productivity, while at the same time permitting more sustainable production management. Studies of AMF species diversity and their functions in different types of land use are crucial for understanding the impact of land use changes on ecosystem services (Soka and Ritchie, 2015).

\section{Isolation of AMF species}

AMF can be identified either by the morphology of their spores or by PCR-based molecular methods, but it is difficult to compare results obtained by different methods in order to estimate AMF diversity (Sasvári and Posta, 2010). Both methods have some intrinsic weaknesses (Sanders, 2004). Most of the studies have relied on spore morphology for AMF identification; however, spore production does not always reflect the abundance of mycorrhizal species in roots (Clapp et al., 1995). To use the morphological method, the AMF species must have sporulated, and sporulation may be affected by environmental conditions. Also, spores from field samples are difficult to identify. To overcome the problem of 'none-sporulating' periods, spore sampling from ecosystems must be repeated over time and trap or bait pot cultures with soil from the 
agro-ecosystems must be established and monitored for the occurrence of spores of specific AMF. However, trap cultures might act as a filter allowing sporulation of only part of the indigenous AMF species which are aggressive enough to colonize and sporulate in a fast-growing host under artificial conditions and in a short time span. Sanders (2004) demonstrated that a taxonomy based solely on morphological characters is influenced by many factors and may not correctly estimate the number of AMF species present due to damaged spores as well as the low sporulation of some species.

Molecular methods may also have problems, firstly because a DNA sequence of a particular gene must be known and correctly identified; the biggest problem, however, is that the genetic variation within a fungal species is high, which may be related to the fact that spores of AMF species may contain several hundred nuclei. According to Sasvári and Posta (2010) using molecular tools to estimate the active colonization of roots by AMF, could give real information about mycorrhizal populations.

\section{Ecological groups of arbuscular mycorrhizal fungi}

It has been shown that AMF community composition depends on host plant species which may have varying degrees of selectivity among AMF species ranging from selective specialists to non-selective. Oehl et al. (2003) were able to group the fungal species into ecological groups. They identified so-called AMF 'generalists' which occur under a wide range of land use systems and others which are 'specialists' which occur only on e.g permanent grasslands.
Some of the generalists are of the genus Glomus, which includes the most widely distributed AMF species in many ecosystems (Sýkorová et al., 2007), such as Gl. diaphanum, and Gl. fasciculatum (now Rhizoglomus fasciculatum), together with Funneliformes mosseae and Fu. geosporum, Claroideoglomus claroideum and Septoglomus constrictum. 'Specialists' in the sense that they occur in specific ecosystems such as permanent grasslands include some sporocarp-building Glomus and Sclerocystis spp. e.g. Gl. mortonii. Some species only or preferentially occur under specific acid (Kuklospora colombiana) or more neutral to alkaline soil conditions ( $F u$. mosseae, Gl. badium) as indicated by Sieverding (1991) and Oehl et al. (2011). It is obvious from the literature on mycorrhiza that some of these generalists are reported from all parts of the world, i.e. from tropical as well as temperate zones, dry and wet climates, infertile and fertile soils, low $\mathrm{pH}$ and higher $\mathrm{pH}$, sandy and clay soils, temporarily-flooded and never-flooded soils, natural and intensively managed ecosystems. This indicates that at least these so-called 'generalists' have been able to invade most existing ecosystems and establish a permanent presence. Other (specialist) species need specific ecological conditions to survive and it appears that many AMF species have a low fitness in intensively managed agro-systems (Oehl et al., 2003).

Gigaspora spp. are frequently developed from spores (Hart and Reader, 2002) and are less common in disturbed agro-ecosystems (Siqueira et al., 1989); they are more common in tropical soils with Sclerocystis spp. Acaulospora species also seem to be better adapted to soils with $\mathrm{pH}$ lower than 5.0 (Siqueira et al., 1984; Bagyaraj, 2014). According to Oehl et al. (2004) there is a pattern of succession 
in AMF sporulation: Glomus species are the first to sporulate while, Acaulospora species do so after the winter period. Scutellospora species sporulate only in autumn, as does Gigaspora species. Previous studies have found members of the Gigasporaceae family, which includes Scutellospora, to be more prevalent in sandy soils (Cuenca and Lovera, 2010; Chaudhary et al., 2014).

The abundance and diversity of AMF are favored by low-input agriculture incorporating planting on raised beds and management practices such as zero tillage that do not disturb the physical properties of soil. Conventional agricultural practices cause loss of AM fungal biodiversity and also selectively favour smaller spores. Strong selection pressure favours sporulation of a certain group of AMF, especially species belonging to genera of the Gigasporaceae family.

At present, little is known about the diversity control of AM fungal communities in some regions; given the increasing importance attached to mycorrhizal fungal diversity for the maintenance of ecosystem functioning, a better understanding of the causes of AMF diversity and its loss is necessary. A better understanding of the influence of land use changes on AMF abundance will help in improving their management, thus leading to improved plant productivity in poor soils; it will also be useful for designing more sustainable management practices (Soka and Ritchie, 2015).

\section{Indicators used to evaluate AMF diversity}

Soils usually contain more than one species of AMF (Barea et al., 2005). In a single rhizosphere, it is possible to find six to eight different morphotypes (Miranda, 2008). A study conducted by Miranda et al. (2005), confirmed that the species richness of AMF is influenced by the associated crop and the type of soil management. The presence of legumes and grasses was associated with an increase in the number of genera and species of AMF over the extended growing season (Cardozo Júnior et al., 2012).

The Shannon diversity index estimates species richness and evenness, and is moderately sensitive to sample size (Zak and Willig, 2004); it takes into account both the number and the relative proportions of taxa in a community. It can range from 0.45 for the AM fungal community in an arable field (Daniell et al., 2001) to 3.0 in a forest habitat (Becerra et al., 2011). According to Brower and Zar (1984), a community with high diversity is characterized by low dominance (few species dominate the AMF community). The Pielou evenness index is used to verify that the distribution among AMF species is uniform.

On the other hand, Wu et al. (2007) found that plant species correlated positively with the abundance of AMF, and Picone (2000) demonstrated that replacement of primary forest by pasture does not create differences in the diversity or dominance of mycorrhizal communities.

The biodiversity index often shows a higher correlation with richness than evenness. Species richness can vary between samples due to numerous ecological variables, such as seasonality and host. Indicators used to evaluate AM fungal communities in different ecosystems are shown in Table 2. 
Table 2. Arbuscular mycorrhizal fungi diversity index (Moreno, 2001).

\begin{tabular}{ll}
\hline Parameter & Formulae \\
\hline Abundance $\left(\mathrm{n}_{i}\right)$ & $\begin{array}{l}\text { Number of spores per species } i \\
\text { Relative abundance (RA) }\end{array}$ \\
$\begin{array}{ll}\mathrm{RA}=\frac{\mathrm{N}^{\circ} \text { of spores for the species (genus) } \times 100}{\text { Total } \mathrm{N}^{\circ} \text { of spores identified }} \\
\text { Isolation frequency (IF) }\end{array}$ & $\mathrm{IF}=\frac{\mathrm{N}^{\circ} \text { soil samples where the species (genus) occurred } \times 100}{\text { Total } \mathrm{N}^{\circ} \text { of soil samples }}$ \\
Shannon-Wiener diversity index $\left(\mathrm{H}^{\prime}\right)$ & $\mathrm{H}^{\prime}=-\sum \mathrm{P}_{i} \ln \left(\mathrm{P}_{i}\right)^{*}$ \\
Pielou's evenness $\left(\mathrm{J}^{\prime}\right)$ & $\mathrm{J}^{\prime}=\mathrm{H}^{\prime} / \log (\mathrm{S})^{* *}$ \\
Simpson dominance index $(l)$ & $l=\sum\left[\mathrm{n}_{i}\left(\mathrm{n}_{i}-1\right)\right] /[\mathrm{N}(\mathrm{N}-1)]$ \\
Simpson diversity index $\left(\mathrm{D}_{\mathrm{s}}\right)$ & $\mathrm{D}_{\mathrm{s}}=1-l$ \\
\hline
\end{tabular}

$* \mathrm{Pi}=\mathrm{ni} / \mathrm{N}$, where $\mathrm{ni}=$ number of individuals of the species $\mathrm{i} ; \mathrm{N}=$ total number of individuals all species (Shannon and Weaver, 1949). ${ }^{*} * \mathrm{H}^{\prime}=$ value obtained by Shannon index, where (S) = total number of species (genera) identified (Pielou, 1975).

Within AM-dominated biomes the composition of AM fungal communities may differ between regions and habitat types. In addition, there were evident differences between ecosystems under different disturbance regimes (Öpik et al., 2006). For example, a low AMF species richness (only 5) was found in the rhizospheric soils associated to pioneer plant species growing at the mouth of lake Budi, Chile (Medina et al., 2015); nevertheless, one of these corresponds to a new specie Corymbiglomus pacificum (Medina et al., 2014). On the contrary, enormous species richness was found in organic tomato in a Mediterranean site with $58 \mathrm{AMF}$ species belonging to 14 genera (Njeru et al., 2015). Maurer et al. (2014) reported $38 \mathrm{AMF}$ species under no-till and in temperate grasslands Oehl et al. (2010) found between 34-39 AMF species and Saito et al. (2004) in Japan reported least amount with 24 taxa at two sites. In forest, the highest taxon richness has been reported in tropical Atlantic Forests with 30 species (Pereira et al., 2014) and tropical forests in Panamá with 29 taxa at three sites (Husband et al., 2002), not unusual in tropical forests. Only one AM fungal taxon was involved in the strictly specific symbiotic relationships with non-photosynthetic plants and liverworts (Russell and Bulman, 2005).

In Chile there are a few reports on AMF diversity in different environments performed since 2004. The aim of this article is to make the distribution of Glomeromycota species in the Southern-Central zone of Chile available to science.

\section{Bibliographical survey of the recorded species in the study area of Southern-Central zone of Chile}

Published descriptions of AMF species were used as the basis for this study. These included the review by Aguilera et al. (2014), together with data provided by Montero Sommerfeld et al. (2013) and Castillo et al. (2004; 2006a; 2006b; 2008; 2010) corresponding to 18 localities. These studies on AMF diversity were grouped into four ecosystem types: forest, grassland, horticultural and crop agro-ecosystem (Table 3). Soil characteristics ( $\mathrm{pH}$, organic matter and available-P) of the ecosystems of the Southern-Central zone of the country in Table 4. 
Table 3. Site description and geographical position of the ecosystems of the Southern-Central zone of Chile.

\begin{tabular}{|c|c|c|c|}
\hline $\begin{array}{c}\text { Ecosystem } \\
\text { symbol }\end{array}$ & $\begin{array}{c}\text { Geographical } \\
\text { location }\end{array}$ & Host & Description \\
\hline EF & $\begin{array}{l}39^{\circ} 30^{\prime}-39^{\circ} 38^{\prime} \mathrm{S} \\
72^{\circ} 02^{\prime}-72^{\circ} 09^{\prime} \mathrm{W}\end{array}$ & $\begin{array}{l}\text { N. dombeyi-L. philippiana; } \\
\text { S. conspicua }\end{array}$ & Evergreen primary forest \\
\hline DF & $\begin{array}{l}39^{\circ} 30^{\prime}-39^{\circ} 38^{\prime} \mathrm{S} \\
72^{\circ} 02^{\prime}-72^{\circ} 09^{\prime} \mathrm{W}\end{array}$ & N. alpina & Secondary forest \\
\hline GF & $\begin{array}{l}39^{\circ} 30^{\prime}-39^{\circ} 38^{\prime} \mathrm{S} \\
72^{\circ} 02^{\prime}-72^{\circ} 09^{\prime} \mathrm{W}\end{array}$ & Natural grassland & Natural grassland \\
\hline NO & $38^{\circ} 46^{\prime} \mathrm{S} ; 72^{\circ} 38^{\prime} \mathrm{W}$ & Natural grassland & $\begin{array}{l}\text { Natural grassland after lupine } \\
\text { with organic fertilization }\end{array}$ \\
\hline $\mathrm{N}$ & $38^{\circ} 46^{\prime} \mathrm{S} ; 72^{\circ} 38^{\prime} \mathrm{W}$ & Natural grassland & $\begin{array}{c}\text { Natural grassland without } \\
\text { fertilization }\end{array}$ \\
\hline GA & $39^{\circ} 47^{\prime} \mathrm{S} ; 7^{\circ} 12^{\prime} \mathrm{W}$ & Grassland & $\begin{array}{l}\text { Four grassland sites with different } \\
\text { long-term management histories }\end{array}$ \\
\hline An & $37^{\circ} 48^{\prime} \mathrm{S} ; 73^{\circ} 41^{\prime} \mathrm{W}$ & C. annuum & Pepper plantation \\
\hline Lo & $38^{\circ} 39^{\prime} \mathrm{S} ; 7^{\circ} 29^{\prime} \mathrm{W}$ & - & Fallow after $L$. sativa \\
\hline $\mathrm{Lu}$ & $38^{\circ} 40^{\prime} \mathrm{S} ; 73^{\circ} 58^{\prime} \mathrm{W}$ & C. annuum & Pepper plantation \\
\hline $\operatorname{Pr}$ & $38^{\circ} 09^{\prime} \mathrm{S} ; 73^{\circ} 00^{\prime} \mathrm{W}$ & C. annuum & Pepper plantation \\
\hline $\mathrm{Sc}$ & $38^{\circ} 15^{\prime} \mathrm{S} ; 72^{\circ} 50^{\prime} \mathrm{W}$ & C. апnиuт & Pepper plantation \\
\hline V1 & $38^{\circ} 40^{\prime} \mathrm{S} ; 72^{\circ} 14^{\prime} \mathrm{W}$ & L. sculentum & Tomato plantation \\
\hline NT & $38^{\circ} 40^{\prime} \mathrm{S} ; 72^{\circ} 31^{\prime} \mathrm{W}$ & T. aestivum & Oat-wheat rotation with no tillage \\
\hline $\mathrm{CT}$ & $38^{\circ} 40^{\prime} \mathrm{S} ; 72^{\circ} 31^{\prime} \mathrm{W}$ & T. aestivum & $\begin{array}{l}\text { Oat-wheat rotation with } \\
\text { conventional tillage }\end{array}$ \\
\hline $\mathrm{Pu}$ & $38^{\circ} 40^{\prime} \mathrm{S} ; 72^{\circ} 31^{\prime} \mathrm{W}$ & T. aestivum & $\begin{array}{l}\text { Oat-wheat rotation with no tillage } \\
\text { and conventional tillage }\end{array}$ \\
\hline $\mathrm{Hu}$ & - & T. aestivum & Oat-wheat rotation \\
\hline $\mathrm{EC}$ & - & T. aestivum & Lupine-wheat rotation \\
\hline Al & - & T. aestivum & Assays in field and trap cultures \\
\hline Go & - & T. aestivum & Field \\
\hline $\mathrm{Cu}$ & - & T. aestivum & Field \\
\hline $\mathrm{OA}$ & $38^{\circ} 34^{\prime} \mathrm{S} ; 72^{\circ} 27^{\prime} \mathrm{W}$ & Avena sativa & Potato-oat in Andisol in pot \\
\hline LA & $38^{\circ} 34^{\prime} \mathrm{S} ; 72^{\circ} 27^{\prime} \mathrm{W}$ & Lupinus sp. & Potato-lupine in Andisol in pot \\
\hline $\mathrm{RA}$ & $38^{\circ} 34^{\prime} \mathrm{S} ; 72^{\circ} 27^{\prime} \mathrm{W}$ & Brassica napus & Potato-rape in Andisol in pot \\
\hline OI & $38^{\circ} 02^{\prime} \mathrm{S} ; 73^{\circ} 06^{\prime} \mathrm{W}$ & Avena sativa & $\begin{array}{l}\text { Natural grassland-oat in Inceptisol } \\
\text { in pot }\end{array}$ \\
\hline LI & $38^{\circ} 02^{\prime} \mathrm{S} ; 7^{\circ} 06^{\prime} \mathrm{W}$ & Lupinus sp. & $\begin{array}{l}\text { Natural grassland-lupine in } \\
\text { Inceptisol in pot }\end{array}$ \\
\hline RI & $38^{\circ} 02^{\prime} \mathrm{S} ; 72^{\circ} 06^{\prime} \mathrm{W}$ & Brassica napus & $\begin{array}{l}\text { Natural grassland-rape in } \\
\text { Inceptisol in pot }\end{array}$ \\
\hline
\end{tabular}


Table 4. Soil characteristics of the ecosystems of Southern-Central zone of Chile.

\begin{tabular}{|c|c|c|c|c|c|c|}
\hline Ecosystem & Symbol & Location & Type of soil & $\mathrm{pH}$ & MO (\%) & $\mathrm{P}\left(\mathrm{mg} \mathrm{kg}^{-1}\right)$ \\
\hline \multirow[t]{2}{*}{ Forest } & EF & Panguipulli & Andisol & 4.6 & 22 & 6 \\
\hline & DF & Panguipulli & Andisol & 5.4 & 25 & 4 \\
\hline \multirow[t]{4}{*}{ Grassland } & GF & Panguipulli & Andisol & 5.4 & 15 & 3 \\
\hline & $\mathrm{NO}$ & Metrenco & Ultisol & $5.8-6.1$ & $11-14$ & $21-17$ \\
\hline & $\mathrm{N}$ & Metrenco & Ultisol & 5.7 & 10 & 12 \\
\hline & GA & Valdivia & Andisol & $5.7-5.8$ & $5-14$ & $4-14$ \\
\hline \multirow[t]{6}{*}{ Horticultural } & An & Angol & Ultisol & 7.3 & 7 & 106 \\
\hline & Lo & Lobería & Inceptisol & 6.1 & 2 & 4 \\
\hline & $\mathrm{Lu}$ & Lumaco & Inceptisol & 5.9 & 6 & 38 \\
\hline & $\operatorname{Pr}$ & Purén & Ultisol & 5.9 & 5 & 48 \\
\hline & $\mathrm{Sc}$ & Los Sauces & Ultisol & 5.5 & 6 & 10 \\
\hline & $\mathrm{Vl}$ & Vilcún & Andisol & 6.1 & 8 & 6 \\
\hline Wheat & NT & Pumalal & Ultisol & 5.8 & 8 & 18 \\
\hline \multirow[t]{4}{*}{ rotation } & $\mathrm{CT}$ & Pumalal & Ultisol & 5.8 & 8 & 22 \\
\hline & $\mathrm{Pu}$ & Pumalal & Ultisol & - & - & - \\
\hline & $\mathrm{Hu}$ & Huichahue & Andisol & 5.4 & 16 & 14 \\
\hline & $\mathrm{EC}$ & El Carmen & Ultisol & 5.3 & 6 & 4 \\
\hline \multirow[t]{3}{*}{ Wheat } & $\mathrm{Al}$ & - & Andisol & 4.5 & 12 & - \\
\hline & Go & Gorbea & Andisol & - & - & - \\
\hline & $\mathrm{Cu}$ & Curacautín & Andisol & - & - & - \\
\hline \multirow[t]{6}{*}{ Others crops } & $\mathrm{OA}$ & Lautaro & Andisol & 6.0 & - & 6 \\
\hline & LA & Lautaro & Andisol & 5.9 & - & 4 \\
\hline & RA & Lautaro & Andisol & 6.0 & - & 8 \\
\hline & OI & Lumaco & Inceptisol & 5.6 & - & 2 \\
\hline & LI & Lumaco & Inceptisol & 5.3 & - & 1 \\
\hline & RI & Lumaco & Inceptisol & 5.5 & - & 5 \\
\hline
\end{tabular}

\section{Arbuscular mycorrhizal fungal species identification}

Morphological: Spores were extracted from $20 \mathrm{~g}$ of soil sampled from the study sites and from trap cultures using the wet sieving technique (Gerdemann and Nicolson, 1963) followed by centrifugation in water and sucrose at $70 \%$. Briefly, AMF spores were passed through sieves of 425, 250, 106, 53 and $32 \mu \mathrm{m}$ and thoroughly washed with distilled water, then separated into morphotypes and mounted on slides using polyvinyl alcohol in lactoglyc- erol (PVLG) and PVLG + Melzer reagent (1:1 v/v) for species identification. Identification was by micromorphological analysis, using the descriptions of AMF found in Schenck and Pérez (1990) and Błaszkowski (2012), and the sites http://www. agro.ar.szczecin.pl/jblaszkowski and http://invam. caf.wvu.edu.

Terminal-restriction fragment length polymorphism and sequencing analyses. Plant root DNA was extracted using cetyltrimethyl ammonium bromide (CTAB) according to a modified protocol of Allen et al. (2006) as described in Krüger et al. 
(2009), and the methodology applied by Montero Sommerfeld et al. (2013). Electropherograms of the sequenced colonies were compared against those in the public databases by BLASTN searches (http://www.ncbi.nlm.nih.gov; Altschul et al., 1997).

\section{Diversity of Glomeromycotean species in the study area}

In this study covering the Southern-Central zone of the country (Table 3 ), a total of 21 genera were found, represented by 57 species of AMF that have been recognized during the last 10 years, equivalent to $21 \%$ of all AMF species described worldwide (Table 5).

The number of different AMF species found ranged from 5 to 29 in specific ecosystems. Four species occurred in 9 to 15 of the 20 locations: $\mathrm{Cl}$. etunicatum (75\%), Ar. trappei (50\%), Cl. claroideum (45\%) were found in all the four ecosystems studied. For our country this species could be described as a "generalist". Rhizoglomus intraradices $(45 \%)$ on the other hand was only found in the agro-ecosystems.

Table 5a. Classification and detection sites of arbuscular mycorrhizal fungal species around of the SouthernCentral zone of Chile.

\begin{tabular}{|c|c|c|c|c|c|c|c|c|c|c|c|c|c|c|c|c|c|c|c|c|}
\hline \multirow{3}{*}{ AMF specie } & \multicolumn{20}{|c|}{ Ecosystem } \\
\hline & \multicolumn{2}{|c|}{ Forest } & \multicolumn{4}{|c|}{ Grassland } & \multicolumn{6}{|c|}{ Horticultural } & \multicolumn{5}{|c|}{ Wheat rotation } & \multicolumn{3}{|c|}{ Wheat } \\
\hline & EF & $\mathrm{DF}$ & GF & NO & $\mathrm{N}$ & GA & An & Lo & $\mathrm{Lu}$ & $\operatorname{Pr}$ & $\mathrm{Sc}$ & $\mathrm{Vl}$ & NT & $\mathrm{CT}$ & $\mathrm{Pu}$ & $\mathrm{Hu}$ & $\mathrm{EC}$ & $\mathrm{Al}$ & Go & $\mathrm{Cu}$ \\
\hline \multicolumn{21}{|l|}{ Acaulospora } \\
\hline $\begin{array}{l}\text { Ac. alpina Oehl, Sýkorová } \\
\text { \& Sieverd. }\end{array}$ & $\mathrm{x}$ & $\mathrm{X}$ & $\mathrm{X}$ & & & & & & $\mathrm{X}$ & & & $\mathrm{X}$ & & & & & & & & \\
\hline Ac. cavernata Blaszk. & & & $\mathrm{X}$ & & & $\mathrm{X}$ & & & & & & & & & & & & & & \\
\hline $\begin{array}{l}\text { Ac. colossica P.A. Schultz, } \\
\text { Bever \& J.B. Morton }\end{array}$ & $\mathrm{x}$ & & $\mathrm{X}$ & & & & & & & & & & & & $\mathrm{X}$ & & & & & \\
\hline Ac. dilatata J.B. Morton. & $\mathrm{X}$ & & $\mathrm{X}$ & & & & & & & & & & & & $\mathrm{X}$ & & & & & \\
\hline Ac. koskei Blaszk. & $\mathrm{x}$ & & $\mathrm{X}$ & & & & & & & & & & & & $\mathrm{X}$ & & & & & \\
\hline Ac. laevis Gerd. \& Trappe & $\mathrm{X}$ & & $\mathrm{X}$ & & & $\mathrm{X}$ & & & & & & $\mathrm{X}$ & & & $\mathrm{X}$ & & & $\mathrm{X}$ & & \\
\hline $\begin{array}{l}\text { Ac. longula Spain \& N.C. } \\
\text { Schenck }\end{array}$ & & $\mathrm{X}$ & $\mathrm{X}$ & & & & & $\mathrm{X}$ & & & & $\mathrm{X}$ & & & & & & $\mathrm{X}$ & & \\
\hline $\begin{array}{l}\text { Ac. mellea Spain \& N.C. } \\
\text { Schenck }\end{array}$ & $\mathrm{x}$ & $\mathrm{X}$ & $\mathrm{X}$ & & & & & & & & & & & & & & $\mathrm{X}$ & & & \\
\hline $\begin{array}{l}\text { Ac. nivalis Oehl, Palenz., } \\
\text { I.C. Sánchez, Kuss, } \\
\text { Sieverd., G.A. Silva. }\end{array}$ & & & & & & $\mathrm{X}$ & & & & & & & & & & & & & & \\
\hline $\begin{array}{l}\text { Ac. paulinae Blaszk. } \\
\text { Ac, punctata Oehl. Palenz }\end{array}$ & & & $\mathrm{X}$ & & & & & & & $\mathrm{X}$ & & $\mathrm{X}$ & & & & & $\mathrm{X}$ & & & \\
\hline $\begin{array}{l}\text { I.C. Sánchez, G.A. } \\
\text { Silva, C. Castillo \& } \\
\text { Sieverd.. }\end{array}$ & & $\mathrm{X}$ & $\mathrm{X}$ & & & & & & & & & & & & & & & & & \\
\hline Ac. scrobiculata Trappe & & & $\mathrm{X}$ & & & & & & & & & & & & & & & & & \\
\hline $\begin{array}{l}\text { Ac. sieverdingii Oehl, } \\
\text { Sýkorová \& Blaszk. }\end{array}$ & & & & & & & & & & & & & & & & & & $\mathrm{X}$ & $\mathrm{X}$ & \\
\hline $\begin{array}{l}\text { Ac. spinosa } \text { C. Walker \& } \\
\text { Trappe }\end{array}$ & $\mathrm{x}$ & & & & & & & & $\mathrm{X}$ & & & $\mathrm{X}$ & & $\mathrm{X}$ & & & & & & \\
\hline $\begin{array}{l}\text { Ac. thomii Blaszk. } \\
\text { Acaulospora spp. }\end{array}$ & & & $\mathrm{X}$ & 1 & & 1 & & & & $\mathrm{X}$ & & 1 & $\mathrm{X}$ & & 2 & & 1 & 1 & & \\
\hline
\end{tabular}


Table 5b. Classification and detection sites of arbuscular mycorrhizal fungal species around of the SouthernCentral zone of Chile.

\begin{tabular}{|c|c|c|c|c|c|c|c|c|c|c|c|c|c|c|c|c|c|c|c|c|}
\hline \multirow{3}{*}{ AMF specie } & \multicolumn{20}{|c|}{ Ecosystem } \\
\hline & \multicolumn{2}{|c|}{ Forest } & \multicolumn{4}{|c|}{ Grassland } & \multicolumn{6}{|c|}{ Horticultural } & \multicolumn{5}{|c|}{ Wheat rotation } & \multicolumn{3}{|c|}{ Wheat } \\
\hline & $\mathrm{EF}$ & DF & GF & $\mathrm{NO}$ & $\mathrm{N}$ & GA & $\mathrm{An}$ & Lo & $\mathrm{Lu}$ & $\operatorname{Pr}$ & $\mathrm{Sc}$ & $\mathrm{Vl}$ & NT & CT & $\mathrm{Pu}$ & $\mathrm{Hu}$ & EC & $\mathrm{Al}$ & Go & $\mathrm{Cu}$ \\
\hline \multicolumn{21}{|l|}{ Ambispora } \\
\hline $\begin{array}{l}\text { Am. gerdemannii C. } \\
\text { Walker, Vestberg \& A. }\end{array}$ & & & & & & & & & & & & & & & & & & $\mathrm{X}$ & & \\
\hline $\begin{array}{l}\text { Schussier } \\
\text { Ambispora spp. }\end{array}$ & & & & & & & & & & & & & & & & & & 1 & 1 & 1 \\
\hline \multicolumn{21}{|l|}{ Archaeospora } \\
\hline $\begin{array}{l}\text { Ar. leptoticha J.B. Morton } \\
\text { \& D. Redecker }\end{array}$ & & $\mathrm{X}$ & & & & & & & & & & & & & & $\mathrm{X}$ & & & & \\
\hline $\begin{array}{l}\text { Ar. myriocarpa Oehl, G.A. } \\
\text { Silva, B.T. Goto \& } \\
\text { Sieverd. }\end{array}$ & & & & & & & & & & & & & & & & & & $\mathrm{X}$ & $\mathrm{X}$ & \\
\hline $\begin{array}{l}\text { Ar. trappei J.B. Morton \& } \\
\text { D. Redecker }\end{array}$ & $\mathrm{X}$ & & $\mathrm{X}$ & & & & $\mathrm{x}$ & & $\mathrm{X}$ & & $\mathrm{X}$ & $\mathrm{X}$ & $\mathrm{X}$ & & & $\mathrm{X}$ & $\mathrm{X}$ & $\mathrm{X}$ & & \\
\hline $\begin{array}{l}\text { Ar. undulata Sieverd., G.A. } \\
\text { Silva, B.T. Goto \& } \\
\text { Oehl. }\end{array}$ & & & & & & & & & $\mathrm{X}$ & & & $\mathrm{X}$ & & & & & & & & \\
\hline \multicolumn{21}{|l|}{$\begin{array}{l}\text { Archaeospora spp. } \\
\text { Cetraspora }\end{array}$} \\
\hline $\begin{array}{l}\text { Ce. gilmorei Oehl, F.A. de } \\
\text { Souza \& Sieverd. }\end{array}$ & & & & & & $\mathrm{X}$ & & & & & & & & & & & & $\mathrm{x}$ & & \\
\hline Cetraspora spp. & & & & & & & & & & & & 1 & & & & & & 1 & & \\
\hline \multicolumn{21}{|l|}{ Claroideoglomus } \\
\hline $\begin{array}{l}\text { Cl. claroideum C. Walker } \\
\text { \& A. Schüssler }\end{array}$ & $\mathrm{X}$ & $\mathrm{X}$ & & & $\mathrm{X}$ & & $\mathrm{X}$ & & $\mathrm{X}$ & & & $\mathrm{X}$ & & & & $\mathrm{X}$ & $\mathrm{X}$ & $\mathrm{X}$ & & \\
\hline $\begin{array}{l}\text { Cl. etunicatum C. Walker } \\
\text { \& A. Schüssler }\end{array}$ & $\mathrm{X}$ & $\mathrm{X}$ & $\mathrm{X}$ & $\mathrm{X}$ & & & $\mathrm{X}$ & $\mathrm{X}$ & $\mathrm{X}$ & & $\mathrm{X}$ & & $\mathrm{X}$ & $\mathrm{X}$ & $\mathrm{X}$ & & $\mathrm{X}$ & $\mathrm{X}$ & $\mathrm{X}$ & $\mathrm{x}$ \\
\hline $\begin{array}{l}\text { Cl. lamellosum C. Walker } \\
\text { \& A. Schüssler }\end{array}$ & & & & & & & & & & & & & & & & & $\mathrm{X}$ & & & \\
\hline $\begin{array}{l}\text { Di. spurca C. Walker \& A. } \\
\text { Schüssler }\end{array}$ & $\mathrm{X}$ & & $\mathrm{X}$ & & & & & $\mathrm{X}$ & & & $\mathrm{X}$ & & $\mathrm{X}$ & & $\mathrm{X}$ & & $\mathrm{X}$ & & & \\
\hline
\end{tabular}

Table 5c. Classification and detection sites of arbuscular mycorrhizal fungal species around of the SouthernCentral zone of Chile.

\begin{tabular}{|c|c|c|c|c|c|c|c|c|c|c|c|c|c|c|c|c|c|c|c|}
\hline \multirow{3}{*}{ AMF specie } & \multicolumn{19}{|c|}{ Ecosystem } \\
\hline & \multicolumn{2}{|c|}{ Forest } & \multicolumn{3}{|c|}{ Grassland } & \multicolumn{6}{|c|}{ Horticultural } & \multicolumn{5}{|c|}{ Wheat rotation } & \multicolumn{3}{|c|}{ Wheat } \\
\hline & $\mathrm{EF}$ & DF & GF & $\mathrm{NO}$ & $\mathrm{N}$ GA & An & Lo & $\mathrm{Lu}$ & $\operatorname{Pr}$ & $\mathrm{Sc}$ & $\mathrm{Vl}$ & NT & CT & $\mathrm{Pu}$ & $\mathrm{Hu}$ & $\mathrm{EC}$ & $\mathrm{Al}$ & Go & $\mathrm{Cu}$ \\
\hline \multicolumn{20}{|l|}{ Dominikia } \\
\hline $\begin{array}{l}\text { Di. epigaea A. Schüssler, } \\
\text { Krüger, C. Walker }\end{array}$ & & & & & & & $\mathrm{X}$ & $\mathrm{x}$ & $\mathrm{x}$ & $\mathrm{x}$ & $\mathrm{X}$ & & & & & & & & \\
\hline Do. aurea & & & & & & & & & & & & & & & & & $\mathrm{X}$ & & \\
\hline \multicolumn{20}{|l|}{ Entrophospora } \\
\hline En. infrequens R.N. Ames & & & & & & & & & & & & & & & & & & & \\
\hline $\begin{array}{l}\text { \& R.W. Schneid. } \\
\text { emend. Oehl \& Sieverd. }\end{array}$ & $\mathrm{X}$ & $\mathrm{X}$ & & & & & & & & & & & & & & & & & \\
\hline \multicolumn{20}{|l|}{$\begin{array}{l}\text { emend. Uenl \& Sieverd. } \\
\text { Funneliformis }\end{array}$} \\
\hline Fu. coronatus Giovann. & & & & & & & & $\mathrm{X}$ & & & $\mathrm{X}$ & $\mathrm{X}$ & $\mathrm{X}$ & $\mathrm{X}$ & & & & & \\
\hline Fu. geosporus C. Walker & $\mathrm{X}$ & & $\mathrm{X}$ & & & & & & & $\mathrm{X}$ & & & & & & & & & \\
\hline $\begin{array}{l}\text { Fu. monosporus Gerd. \& } \\
\text { Trappe }\end{array}$ & & & & & & & & & & & $\mathrm{X}$ & & & & & & & & \\
\hline $\begin{array}{l}\text { Fu. mosseae C. Walker \& } \\
\text { A. Schüssler }\end{array}$ & & & & & & & & $\mathrm{X}$ & & $\mathrm{x}$ & $\mathrm{X}$ & & & & $\mathrm{X}$ & $\mathrm{x}$ & $\mathrm{x}$ & & $\mathrm{x}$ \\
\hline \multicolumn{20}{|l|}{ Gigaspora } \\
\hline Gigaspora spp. & & & & & & 1 & & & & & & & & & & 1 & & & \\
\hline \multicolumn{20}{|l|}{ Glomus } \\
\hline $\begin{array}{l}\text { Gl. ambisporum G.S. Sm. } \\
\text { \& N.C. Schenck }\end{array}$ & & & & & & & & & & & & & & & $\mathrm{x}$ & & & & \\
\hline Gl. brohultii Sieverd. & & & $\mathrm{X}$ & & & & & & & & & & & & & & & & \\
\hline $\begin{array}{l}\text { Gl. clavisporum Almeida } \\
\text { \& N.C. Schenck }\end{array}$ & & & & & & $\mathrm{x}$ & & & & & & & & & & & & & \\
\hline $\begin{array}{l}\text { Gl. diaphanum J.B. Morton } \\
\text { \& C. Walker }\end{array}$ & & & $\mathrm{X}$ & & & & & & $\mathrm{X}$ & & $\mathrm{X}$ & $\mathrm{X}$ & $\mathrm{X}$ & $\mathrm{X}$ & & & $\mathrm{x}$ & & \\
\hline $\begin{array}{l}\text { Gl. macrocarpum Tul. \& } \\
\text { C. Tul. }\end{array}$ & $\mathrm{X}$ & $\mathrm{X}$ & $\mathrm{X}$ & & & & & $\mathrm{x}$ & & & & $\mathrm{X}$ & & $\mathrm{X}$ & & & & & $\mathrm{x}$ \\
\hline Gl. pallidum I.R. Hall & & & & & & $\mathrm{X}$ & $\mathrm{X}$ & $\mathrm{X}$ & & & $\mathrm{X}$ & & & & & & & & \\
\hline $\begin{array}{l}\text { Gl. vesiculiferum } \text { C. } \\
\text { Walker \& A Schüssler }\end{array}$ & & & & & & & & $\mathrm{X}$ & & & & & & & & & & & \\
\hline Glomus spp. & & & & 8 & 7 & & & & & & & & & 2 & 1 & 1 & 2 & & \\
\hline
\end{tabular}


Table 5d. Classification and detection sites of arbuscular mycorrhizal fungal species around of the SouthernCentral zone of Chile.

\begin{tabular}{|c|c|c|c|c|c|c|c|c|c|c|c|c|c|c|c|c|c|c|c|c|}
\hline \multirow{3}{*}{ AMF specie } & \multicolumn{20}{|c|}{ Ecosystem } \\
\hline & \multicolumn{2}{|c|}{ Forest } & \multicolumn{4}{|c|}{ Grassland } & \multicolumn{6}{|c|}{ Horticultural } & \multicolumn{5}{|c|}{ Wheat rotation } & \multicolumn{3}{|c|}{ Wheat } \\
\hline & $\mathrm{EF}$ & $\mathrm{DF}$ & GF & NO & $\mathrm{N}$ & GA & An & Lo & $\mathrm{Lu}$ & $\operatorname{Pr}$ & Sc & $\mathrm{Vl}$ & NT & $\mathrm{CT}$ & $\mathrm{Pu}$ & $\mathrm{Hu}$ & EC & $\mathrm{Al}$ & Go & $\mathrm{Cu}$ \\
\hline \multicolumn{21}{|l|}{ Intraspora } \\
\hline $\begin{array}{l}\text { In. schenkii Sieverd. \& S. } \\
\text { Toro }\end{array}$ & $\mathrm{X}$ & & $\mathrm{X}$ & & & & & & & & & & & & $\mathrm{X}$ & & & & & \\
\hline \multicolumn{21}{|l|}{ Pacispora } \\
\hline $\begin{array}{l}\text { Pa. dominikii Oehl \& } \\
\text { Sieverd. }\end{array}$ & & & $\mathrm{X}$ & & & & & $\mathrm{X}$ & & & & $\mathrm{X}$ & & & $\mathrm{X}$ & & $\mathrm{X}$ & $\mathrm{X}$ & & \\
\hline Pacispora spp. & 2 & 1 & & & & & & & & & & & & & & & 1 & & & \\
\hline \multicolumn{21}{|l|}{ Paraglomus } \\
\hline $\begin{array}{l}\text { P. occultum J.B. Morton } \\
\text { \& D. Redeker }\end{array}$ & & & $\mathrm{X}$ & & & & & & $\mathrm{X}$ & & $\mathrm{X}$ & $\mathrm{X}$ & & & & $\mathrm{X}$ & & $\mathrm{X}$ & $\mathrm{X}$ & $\mathrm{X}$ \\
\hline P. laccatum Blaszk. & & & $\mathrm{X}$ & & & & & & & & & & & & & & & & & \\
\hline \multicolumn{21}{|l|}{ Racocetra } \\
\hline $\begin{array}{l}\text { Ra. weresubiae Koske \& } \\
\text { C. Walker }\end{array}$ & & & $\mathrm{X}$ & & & & & & & & & & & & & & & & & \\
\hline \multicolumn{21}{|l|}{ Rhizoglomus } \\
\hline $\begin{array}{l}\text { R. aggregatum N.C. } \\
\text { Schenck \& G.S. Sm. }\end{array}$ & & & & & & & & & & & & $\mathrm{X}$ & & & & & & & & \\
\hline $\begin{array}{l}\text { R. fasciculatum C. Walker } \\
\text { \& Koske }\end{array}$ & & $\mathrm{X}$ & & & & & & $\mathrm{X}$ & $\mathrm{X}$ & & & $\mathrm{X}$ & & & & $\mathrm{X}$ & & & $\mathrm{X}$ & $\mathrm{X}$ \\
\hline $\begin{array}{l}\text { R. intraradices N.C. } \\
\text { Schenck \& G.S. Sm. }\end{array}$ & & & & & & & $\mathrm{X}$ & $\mathrm{X}$ & & $\mathrm{X}$ & & & $\mathrm{X}$ & $\mathrm{X}$ & $\mathrm{X}$ & & & $X$ & $\mathrm{X}$ & $\mathrm{X}$ \\
\hline R. invermaium I.R. Hall & $\mathrm{X}$ & & & & & $\mathrm{X}$ & & & & & & & $\mathrm{X}$ & $\mathrm{X}$ & & & & & $\mathrm{X}$ & $\mathrm{X}$ \\
\hline R. microaggregatum & & & & & & & & & & & & & & & & & & & & \\
\hline Koske, Gemma \& & & & & & & & & & & & & & & & & & & & $\mathrm{X}$ & \\
\hline \multirow{2}{*}{\multicolumn{21}{|c|}{ Sacculospora }} \\
\hline & & & & & & & & & & & & & & & & & & & & \\
\hline Sa. baltica Blaszk. & & $\mathrm{X}$ & & & & & & & & & & & & & & & & & & \\
\hline Sclerocystis & & & & & & & & & & & & & & & & & & & & \\
\hline $\begin{array}{l}\text { Sc. rubiformis Gerd. \& } \\
\text { Trappe }\end{array}$ & $\mathrm{X}$ & $\mathrm{X}$ & & & & & & & & & & & & & $\mathrm{X}$ & & & & & \\
\hline Sc. sinuosa Gerd. \& Bakshi & & & & & & & & & & & & & & & & & & & $\mathrm{X}$ & \\
\hline
\end{tabular}

Table 5e. Classification and detection sites of arbuscular mycorrhizal fungal species around of the SouthernCentral zone of Chile.

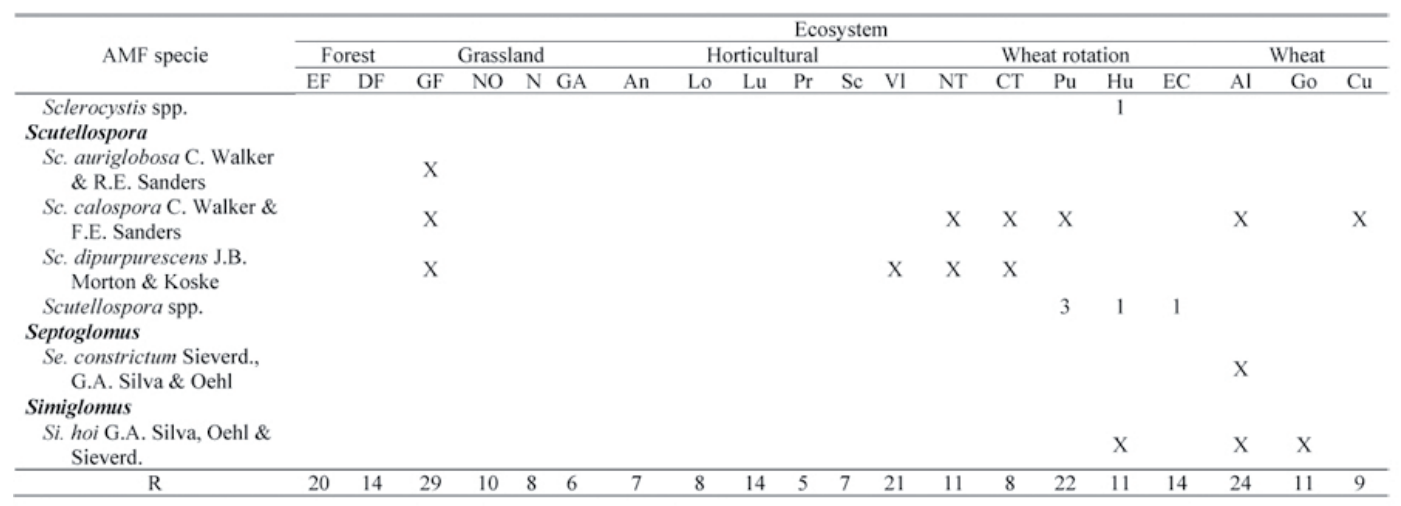

Others were rare species unique in their ecosystems. In forest: Sa. baltica; in grassland: Ac. nivalis, Ac. scrobiculata, Gl. brohultii, Pa. laccatum, Ra. weresubiae, Sc. auriglobosa; in horticultural agro-ecosystems: Fu. monosporum, Gl. clavisporum, Gl. vesiculiferum, R. aggregatum, and in crop agro-ecosystems:
Am. gerdemannii, Do. aurea, Gl. ambisporum, Rh. microaggregatum, Sc. sinuosa, and Se. constrictum. These species are denominated "specialists".

The families with the most species recorded in the Southern-Central zone of the country were Glomeraceae (19) and Acaulosporaceae (15), followed 
by Archaeosporaceae (5), Entrophosporaceae (4), Scutellosporaceae (3), Diversisporaceae (2), Paraglomeraceae (2) Racocetraceae (2), Sclerocystis (2), and finally Ambisporaceae, Gigasporaceae, Pacisporaceae, and Sacculosporaceae with only one species each (Table 5).

Of the 38 known genera of AMF, 15 were not recorded in this survey: Albahypha, Corymbiglomus, Dentiscutata, Fuscutata, Geosiphon, Intraornatospora, Kamienskia, Kuklospora, Paradentiscutata, Quatu- nica, Viscospora, Orbispora, Otospora, Redeckera, and Tricispora.

In the two Chilean forest ecosystems (Figure 1A) most species were from Diversisporales, followed by Glomerales and Archaeosporales. In pasture ecosystems (Figure 1B), also most species were from $\mathrm{Di}$ versisporales, while in the agro-ecosystems (Figures 1C and 1D) Glomerales spp. dominated, followed in several locations by Diversiporales and in others by Archaeosporales.
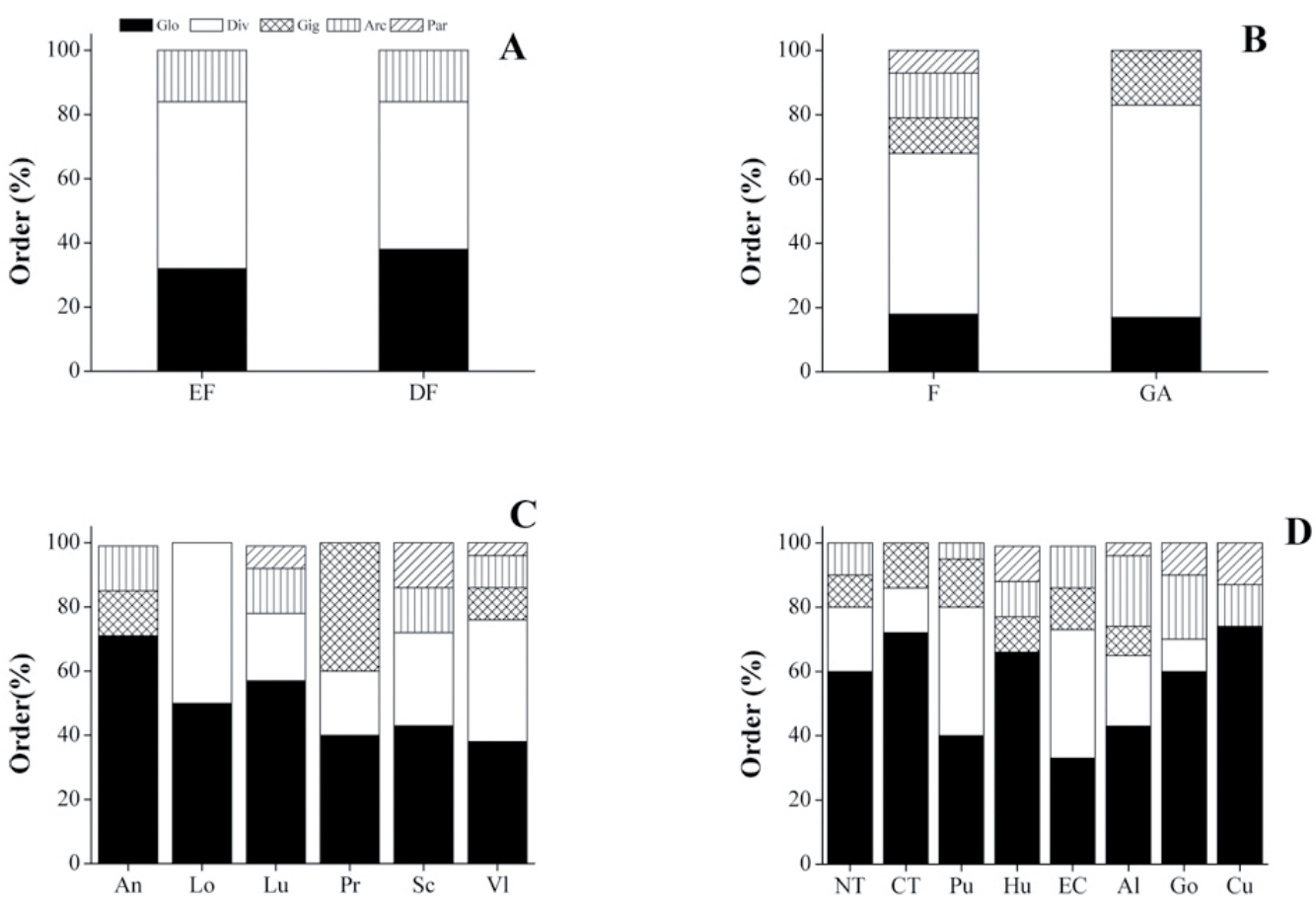

Figure 1. Arbuscular mycorrhizal fungi orders distribution in ecosystems of the Southern-Central zone of Chile: Forest (A), Grassland (B), Horticultural (C), and Wheat rotation (D). Glo: Glomerales; Div: Diversisporales; Gig: Gigasporales; Arc: Archaeosporales; Par: Paraglomerales. 
In three ecosystems (forest, grassland and wheat agroecosystems) Acaulosporaceae was the predominant family with $27 \%$ to $41 \%$; in horticultural agro-eco- systems, Glomeraceae was the predominant family with $38 \%$ (Table 6).

Table 6. Distribution of arbuscular mycorrhizal fungi families in ecosystems of the Southern-Central zone of Chile.

\begin{tabular}{|c|c|c|c|c|c|}
\hline \multirow[b]{2}{*}{ Order } & \multirow[b]{2}{*}{ Familie } & \multicolumn{2}{|c|}{ Agroecosystems } & \multicolumn{2}{|c|}{ Ecosystems } \\
\hline & & $\begin{array}{c}\text { Horticultural } \\
(\%)\end{array}$ & $\begin{array}{c}\text { Wheat } \\
(\%)\end{array}$ & $\begin{array}{c}\text { Grassland } \\
(\%)\end{array}$ & $\begin{array}{c}\text { Forest } \\
(\%)\end{array}$ \\
\hline \multirow[t]{2}{*}{ Glomerales } & Glomeraceae & 38 & 27 & 16 & 16 \\
\hline & Entrophosporaceae & 7 & 10 & 6 & 13 \\
\hline \multirow[t]{4}{*}{ Diversisporales } & Diversisporaceae & 7 & 3 & 3 & 4 \\
\hline & Sacculosporaceae & 0 & 0 & 0 & 4 \\
\hline & Pacisporaceae & 4 & 5 & 3 & 8 \\
\hline & Acaulosporaceae & 24 & 27 & 41 & 38 \\
\hline \multirow[t]{3}{*}{ Gigasporales } & Scutellosporaceae & 4 & 7 & 6 & 0 \\
\hline & Racocetraceae & 3 & 5 & 6 & 0 \\
\hline & Gigasporaceae & 3 & 2 & 0 & 0 \\
\hline \multirow[t]{2}{*}{ Archaeosporales } & Ambisporaceae & 0 & 5 & 0 & 4 \\
\hline & Archaeosporaceae & 7 & 7 & 13 & 13 \\
\hline Paraglomerales & Paraglomeraceae & 3 & 2 & 6 & 0 \\
\hline
\end{tabular}

According to the distribution and prospecting of fungi from the Southern-Central zone of Chile, the following biodiversity indices were obtained: natural grassland (GF) showed the highest AMF species richness (29) followed by evergreen forest (EF) (20); while managed prairie (GA) had the lowest richness (6). Pielou's evenness index was similar in different agro-ecosystems; lupine
(LI) (0.93) presented the highest evenness index and wheat (Al) (0.46 to 0.55$)$ the lowest. Overall, Shannon's diversity index was high in all agroecosystems (1.8 to 2.6), being less dominant in lupine (LI) (0.09). The highest value of Simpson's index was found in EF (0.29), coinciding with the highest number of spores (3164 spores $100 \mathrm{gss}^{-1}$ ) (Table 7). 
Table 7. Arbuscular mycorrhizal fungi diversity index in ecosystems of the Southern-Central zone of Chile.

\begin{tabular}{lcccccc}
\hline \multicolumn{1}{c}{ Ecosystem } & Symbol & R & E & H' $^{\prime}$ & S & N $^{\circ}$ spores \\
\hline Forest & EF & 20 & 0.62 & 1.82 & 0.29 & $3164^{\mathrm{a}}$ \\
Grassland & DF & 14 & 0.70 & 1.81 & 0.24 & $456^{\mathrm{a}}$ \\
& GF & 29 & 0.72 & 2.19 & 0.15 & $1001^{\mathrm{a}}$ \\
& NO & 10 & $0.68-0.80$ & $1.6-1.8$ & - & $840-1200^{\mathrm{a}}$ \\
Wheat rotation & $\mathrm{N}$ & 8 & 0.76 & 1.6 & - & $640^{\mathrm{a}}$ \\
Wheat & GA & 6 & - & - & - & - \\
Other crops & Pu & $10-20$ & $0.78-0.88$ & $1.8-2.5$ & - & $150-700^{\mathrm{b}}$ \\
& $\mathrm{Al}$ & $15-19$ & $0.46-0.55$ & $2.08-2.39$ & $0.10-0.19$ & $80-260^{\mathrm{a}}$ \\
& OA & 33 & 0.69 & 2.4 & 0.18 & $550^{\mathrm{b}}$ \\
& LA & 23 & 0.84 & 2.6 & 0.09 & $180^{\mathrm{b}}$ \\
& RA & 23 & 0.79 & 2.4 & 0.11 & $390^{\mathrm{b}}$ \\
& OI & 22 & 0.73 & 2.3 & 0.15 & $420^{\mathrm{b}}$ \\
& LI & 13 & 0.93 & 2.4 & 0.09 & $50^{\mathrm{b}}$ \\
& RI & 11 & 0.81 & 2.0 & 0.18 & $50^{\mathrm{b}}$ \\
\hline
\end{tabular}

$\mathrm{N}^{\circ}$ spores: ${ }^{\mathrm{N}} \mathrm{N}^{\circ} 100 \mathrm{gss}^{-1},{ }^{\mathrm{b}} \mathrm{N}^{\circ} 100 \mathrm{~mL}$ soil ${ }^{-1}$. R: richness; E: evenness; H': Shannon-Wiener; S; Simpson index

A total of 57 AMF species have been detected during the last 10 years in Chilean soils, equivalent to $21 \%$ of global diversity; this is an astonishingly low number, when about 270 species have been classified worldwide for the phylum Glomeromycota (Silva et al., 2014). The number of AMF species can reach up to $60-70$ in a relatively small region like the Upper Rhine Valley where Germany, France and Switzerland meet (Sieverding and Oehl, 2005).

In agro-ecosystems, some species were recorded in low numbers; the rarity of some species may reflect their narrow adaptability in contrast to several Glomeraceae species, which have proved more adaptable. All the information currently available indicates that Glomus spp. is far more frequent than any of the other genera of AM. Schenck and Kinloch (1980) attributed the abundance of Glomus species in the soils to their wide adaptability to different plants and environmental conditions, citing the fact that Gl. intraradices (now Rhizoglomus intraradices) was found in 9 of the 18 agro-ecosystems (horticultural and crop agroecosystems); on the other hand it was absent from forest and grassland. Douds and Schenck (1990) reported that Gl. intraradices has been found to be less sensitive to $\mathrm{P}$ and $\mathrm{N}$ fertilization, suggesting that the intracortical sporulation of Gl. intraradices may reduce the path of carbon flux and could contribute to the relative insensitivity of this species to fertilization. While Acaulospora spp. are also found regularly, Scutellospora spp., Entrophospora spp. and Pacispora spp. are less frequent. In tropical agro-ecosystems Acaulospora spp., Glomus spp. and Scutellospora spp. may present the same high frequency, and Entrophospora spp. and Gigaspora spp. are also often observed, while Pacispora spp. are extremely rare (Mello et al., 2013).

In forest ecosystems, Glomus spp. were present in $19 \%$ of the total. The genus Glomus is reported to be the dominant AMF in some forest ecosystems (Tamuli and Boruah, 2002). The genus Glomus is reported to be the dominant AMF in some forest ecosystems.

The genus Intraspora has been found in Brazil, Argentina, and the Swiss Alps (Sieverding and Oehl, 2006; Cardozo-Júnior et al., 2012), while in Chile it was 
only found in EF and GF. Souza et al. (2010) noted that members of the genus Intraspora are often found in pastures.

Similar results, as just mentioned above, were detected when compared with other studies. Data from semiarid and arid areas show that the richness varies from 3 to 32 AMF species (Yang et al., 2010; Alguacil et al., 2012; Pagano et al., 2013). In the evergreen forests and pastures of Nicaragua and Costa Rica, 28 AMF species have been registered (Picone, 2000), whereas in the oak savannahs of USA 18 AMF species were found (Landis et al., 2004). Furthermore, according to Becerra et al. (2011) the genus Acaulospora contributed most to the biodiversity in a forest in Argentina. Finally, Kumar and Garampalli (2013) suggested that future research on AMF biodiversity in a complex habitat should combine the molecular, morphological and biochemical approaches. So far, this has been done only once (Wetzel et al., 2014).

\section{Final considerations and conclusions}

These results on the occurrence and distribution of AMF in the Southern-Central zone of the Chile reinforce the importance of inventories and studies in areas which have not yet been explored, in order to extend knowledge concerning this important group of fungi. The genetic variations among AMF species and between individuals of the same species may influence their compatibility with plants and determine their beneficial effects on the host plants. Knowledge of these aspects may help to elucidate the different roles of AMF in several plant species, and in specific environmental conditions of agro-ecosystems and ecosystems.

\section{Acknowledgements}

The authors thank of the Chilean National Commission for Scientific and Technological Research (FONDECYT, grants $\mathrm{N}^{\circ} 1100642, \mathrm{~N}^{\circ} 1120890, \mathrm{~N}^{\circ} 1090455$, $\mathrm{N}^{\circ} 11090014, \mathrm{~N}^{\circ} 1130541, \mathrm{~N}^{\circ} 1070283, \mathrm{~N}^{\circ} 1020306$, and $\left.\mathrm{N}^{\circ} 7040062\right)$ for information obtained for the manuscript.

\section{References}

Abbott, L.K., Robson, A.D. 1991. Factors influencing the occurrence of vesicular-arbuscular mycorrhizas. Agric. Ecosyst. Environ. 35, 121-150.

Aguilera, P., Cornejo, P., Borie, F., Barea, J.M., von Baer, E., Oehl, F. 2014. Diversity of arbuscular mycorrhizal fungi associated with Triticum aestivum L. plants growing in an Andosol with high aluminum level. Agric. Ecosyst. Environ. 186, 178-184.

Alguacil, M.M., Lumini, E., Roldán, A., Salinas-García, J.R., Bonfante, P., Bianciotto, V. 2012. The impact of tillage practices on arbuscular mycorrhizal fungal diversity in subtropical crops. Ecol. Appl. 18, 527-536.

Altschul, S.F., Madden, T.L., Schaffer, A.A., Zhang, J.H., Zhang, Z., Miller, W., Lipman, D.J. 1997. Gapped BLAST and PSI-BLAST: a new generation of protein database search programs. Nucleic Acids Res. 25, 3389-3402.

Allen, G.C., Flores-Vergara, M.A., Krasnyanski, S., Kumar, S., Thompson, W.F. 2006. A modified protocol for rapid DNA isolation from plant tissues using cetyltrimethylammonium bromide. Nature Protocols. 1, 2320-2325.

Augé, R.M. 2001. Water relations, drought and vesicular arbuscular mycorrhizal symbiosis. Mycorrhiza. 11, 3-42. 
Bagyaraj, D.J. 2014. Ecology of arbuscular mycorrhizal fungi. In: R.N. Kharwar, R. Upadhyay, N. Dubey, R. Raghuwanski (eds). Microbial Diversity and Biotechnology in Food Security. SpringerLink, India, pp: 133-146.

Barea, J.M., Pozo, M.J., Azcón, R., Azcón-Aguilar, C. 2005. Microbial co-operation in the rhizosphere. J. Exp. Bot. 56, 1761-1778.

Becerra, A.G., Cabello, M.N., Bartoloni, N.J. 2011. Native arbuscular mycorrhizal fungi in the Yungas forests, Argentina. Mycologia. 103, 273-279.

Bever, J.D., Morton, J.B., Antonovics, J., Schultz, P.A. 1996. Host-dependent sporulation and species diversity of mycorrhizal fungi in a mown grassland. J. Ecol. 75, 1965-1977.

Blaszkowski, J. 2012. Glomeromycota. W. Szafer Institute of Botany, Polish Academy of Sciences, Kraków, 303 p.

Blaszkowski, J., Chwat, G., Góralska, A., Ryszka, P., Kovács, G.M. 2015. Two new genera, Dominikia and Kamienska, and D. disticha sp. nov. in Glomeromycota. Nova Hedwigia. 100, 225-238.

Blaszkowski, J., Chwat, G., Kovács, G.M., Gáspár, B.K., Ryszka, P., Orlowska, E., Pagano, M.C., Araújo, F.S., Wubet, T., Buscot, F. 2013. Septoglomus fuscum and $S$. furcatum, two new species of arbuscular mycorrhizal fungi (Glomeromycota). Mycologia. 105, 670-680.

Boddington, C.L., Dodd, J.C. 2000. The effect of agricultural practices on the development of indigenous arbuscular mycorrhizal fungi. II. Studies in experimental microcosms. Plant Soil. 218, 145-157.

Borie, F., Rubio, R., Rouanet, J.L., Morales, A., Borie, G., Rojas, C. 2006. Effects of tillage systems on soil characteristics, glomalin and mycorrhizal propagules in a Chilean Ultisol. Soil Till. Res. 88, 253-261.
Borriello, R., Lumini, E., Girlanda, M., Bonfante, P., Bianciotto, V. 2012. Effects of different management practices on arbuscular mycorrhizal fungal diversity in maize fields by a molecular approach. Biol. Fertil. Soils. 48, 911-922.

Brower, J.E., Zar, J.H. 1984. Community similarity. In: J.E. Brower, J.H. Zar (eds). Field \& Laboratory Methods for General Ecology. Dubuque, Win C. Brown Publishers, pp: 226.

Cardozo Júnior, F.M., Carneiro, R.F.V., Goto, B.T., Bezerra, A.A.C., Araújo, A.S.F., Nunes, L.A.P.L. 2012. Arbuscular mycorrhizal fungi in degraded lands in Northeast Brazil. African J. Microbiol. Res. 6, 7198-7205.

Carvalho, L.M., Correia, P.M., Caçador, I., MartinsLouçao, M.A. 2003. Effects of salinity and flooding on the infectivity of salt marsh arbuscular mycorrhizal fungi in Aster tripolium L. Biol. Fert. Soils. 38, 137-143.

Castillo, C.G., Rubio, R., Borie, F., Sieverding, E. 2010. Diversity of arbuscular mycorrhizal fungi in horticultural production systems of Southern Chile. J. Soil Sci. Plant Nutr. 10, 407-413.

Castillo, C.G., Astroza, I., Borie, F., Rubio, R. 2008. Efecto de cultivos hospederos y no hospederos sobre propágulos micorrícicos arbusculares. R.C. Suelo Nutr. Veg. 8, 37-54.

Castillo, C.G., Rubio, R., Rouanet, J.L., Borie, F. 2006a. Early effects of tillage and crop rotation on arbuscular mycorrhizal fungal propagules in an Ultisol. Biol. Fertil. Soils. 43, 83-92.

Castillo, C.G., Borie, F., Godoy, R., Rubio, R., Sieverding, E. 2006b. Diversity of mycorrhizal plants species and arbuscular mycorrhizal fungi in evergreen forest, deciduous forest and grassland ecosystems of Southern Chile. J. Appl. Bot. Food Qual. 80, 40-47. 
Castillo, C.G., Rubio, R., Contreras, A., Borie, F. 2004. Arbuscular mycorrhizal fungi in an Ultisol from IXth Region fertilized with organic manure. R.C. Suelo Nutr. Veg. 4, 39-47.

Chaudhary, V.B., O’Dell, T.E., Rillig, M.C., Johnson, N.C. 2014. Multiscale patterns of arbuscular mycorrhizal fungal abundance and diversity in semiarid shrublands. Fungal Ecol. 12, 32-43.

Clapp, J.P., Young, J.P.W., Merryweather, J.W., Fitter, A.H. 1995. Diversity of fungal symbionts in arbuscular mycorrhizas from a natural community. New Phytol. 130, 259-265.

Cuenca, G., Lovera, M. 2010. Seasonal variation and distribution at different soil depths of arbuscular mycorrhizal fungi spores in a tropical Sclerophyllous shrubland. Bot. 88, 54-64.

Daniell, T.J., Husband, R., Fitter, A.H., Young, J.P.W. 2001. Molecular diversity of arbuscular mycorrhizal fungi colonizing arable crops. Fems Microbiol. Ecol. 36, 203-209.

Douds, D.D., Schenck, N.C. 1990. Increased sporulation of vesicular-arbuscular mycorrhizal fungi by manipulation of nutrient regimes. Appl. Environ. Microbiol. 56, 413-418.

Egerton-Warburton, L.M., Allen, E.B. 2000. Shifts in arbuscular mycorrhizal communities along an anthropogenic nitrogen deposition gradient. Ecol. Appl. 10, 484-496.

Gerdemann, J.W., Nicolson, T.H. 1963. Spores of Mycorrhizal Endogone species extracted from soil by wet sieving and decanting. Trans British Mycol. Soc. 46, 235-244.

Goto, B.T., Silva, G.A., Assis, D.M.A., Silva, D.K.A., Souza, R.G., Ferreira, A.C.A., Jobim, K., Mello, C.M.A., Vieira, H.E.E., Maia, L.C., Oehl, F. 2012. Intraornatosporaceae (Gigasporales), a new family with two new genera and two new species. Mycotaxon. 119, 117-132.
Hart, M.M., Reader, R.J. 2002. Taxonomic basis for variation in the colonization strategy of arbuscular mycorrhizal fungi. New Phytol. 153, 335-344.

Hartnett, D.C., Wilson, G.W.T. 1999. Mycorrhizae influence plant community structure and diversity in tallgrass prairie. Ecol. 80, 1187-1195.

Helgason, T., Daniell, T.J., Husband, R., Fitter, A.H., Young, J.P.W. 1998. Ploughing up the wood-wide web? Nature. 394, 431.

Husband, R., Herre, E.A., Turner, S.L., Gallery, R., Young, J.P.W. 2002. Molecular diversity of arbuscular mycorrhizal fungi and patterns of host association over time and space in a tropical forest. Molecular Ecol. 11, 2669-2678.

Johnson, N.C., Pfleger, F.L. 1992. Vesicular-arbuscular mycorrhizae and cultural stress. In: G.J. Bethlenfalvay, R.G. Lindenman (eds). Mycorrhizae in Sustainable Agriculture. Am. Soc. Agron. Special PubHcalion 54, Madison, pp: 71-99.

Johnson, N.C., Tilman, D., Wedin, D. 1992. Plant and soil controls on mycorrhizal fungal communities. Ecol. 73, 2034-2042.

Krüger, M., Stockinger, H., Krüger, C., Schussler, A. 2009. DNA-based species level detection of Glomeromycota: one PCR primer set for all arbuscular mycorrhizal fungi. New Phytol. 183, 212-223.

Kumar, C.P.S., Garampalli, R.H. 2013. Diversity of arbuscular mycorrhizal fungi in irrigated and nonirrigated fields of southern Karnataka, India. J. Environ. Biol. 34, 159-164.

Landis, F.C., Gargas, A., Givnish, T.J. 2004. Relationships among arbuscular mycorrhizal fungi, vascular plants and environmental conditions in oak savannas. New Phytol. 164, 493-504. 
Liu, Y., Shi, G.X., Mao, L., Cheng, G., Jiang, S., Ma, S., An, L., Du, G., Johnson, N.C., Feng, H. 2012. Direct and indirect influences of eight years of nitrogen and phosphorus fertilization on Glomeromycota in an alpine meadow ecosystem. New Phytol. 194, 523-535.

Lugo, M., Cabello, M. 2002. Native arbuscular mycorrhizal fungi (AMF) from mountain grassland (Córdoba, Argentina) I. Seasonal variation of fungal spore diversity. Mycologia. 94, 579-586.

Marinho, F., Silva, G.A., Ferreira, A.C.A., Veras, J.S.N., Sousa, N.M.F., Goto, B.T., Maia, L.C., Oehl, F. 2014. Bulbospora minima, new genus and new species in the Glomeromycetes from semiarid Northeast Brazil. Sydowia. 66, 313-323.

Maurer, C., Rüdy, M., Chervet, A., Sturny, W., Flisch, R., Oehl, F. 2014. Diversity of arbuscular mycorrhizal fungi in field crops using no-till and conventional tillage practices. Agrarforschung Schweiz. 5, 398-405.

Medina, J., Meier, S., Rubio, R., Curaqueo, G., Borie, F., Aguilera, P., Oehl, F., Cornejo, P. 2015. Arbuscular mycorrhizal status of pioneer plants from the mouth of lake Budi, Araucanía Region, Chile. J. Soil Sci. Plant Nutr. 15, 152-152.

Medina, J., Cornejo, P., Borie, F., Meyer, S., Palenzuela, J., Vieira, H.E.E., Ferreira, A.C.A., Silva, G.A., Sánchez-Castro, I., Oehl, F. 2014. Corymbiglomus pacificum, a new Glomeromycete from a saline lakeshore in Chile. Mycotaxon. 127, 173183.

Mello, C.M.A., Silva, G.A., Assis, D.M.A., Pontes, J.S., Ferreira, A.C.A., Leão, M.P.C., Vieira, H.E.E., Maia, L.C., Oehl, F. 2013. Paraglomus pernambucanum sp. nov. and Paraglomus bolivianum com. nov. and biogeographic distribution of Paraglomus and Pacispora. J. Appl. Bot. Food Qual. 86, 113-125.
Miller, S.P., Bever, J.D. 1999. Distribution of arbuscular mycorrhizal fungi in stands of the wetland grass Panicum hemitomon along a wide hydrologic gradient. Oecologia. 119, 586-592.

Miranda, J.C.C. 2008. Cerrado: micorriza arbusculaocorrência e manejo. Planaltina, Embrapa Cerrados, Brasil, 169 p.

Miranda, J.C.C., Vilela, L., Miranda, L.N. 2005. Dinamica e contribuicao da micorriza arbuscular em sistemas de producao com rotacao de culturas. Pesq. Agropec. Bras. 40, 1005-1014.

Montero Sommerfeld, H., Díaz, L.M., Alvarez, M., Añazco Villanueva, C.A., Matus, F., Boon, N., Boeckx, P., Huygens, D. 2013. High winter diversity of arbuscular mycorrhizal fungal communities in shallow and deep grassland soils. Soil Biol. Biochem. 65, 236-244.

Moreno, C. 2001. Métodos para medir la biodiversidad. M6T-Manuales y Tesis. SEA, Zaragoza, 84 p.

Njeru, E.M., Avio, L., Bocci, G., Sbrana, C., Turrini, A., Bàrberi, P., Giovannetti, M., Oehl, F. 2015. Contrasting effects of cover crops on 'hot spot' arbuscular mycorrhizal fungal communities in organic tomato. Biol. Fertil. Soils. 51, 151-166.

Oehl, F., Sánchez-Castro, I., Palenzuela, J., Silva, G.A. 2015. Palaeospora spainii, a new arbuscular mycorrhizal fungus from Swiss agricultural soils. Nova Hedwigia. 101, 89-102.

Oehl, F., Sieverding, E., Palenzuela, J., Ineichen, K., da Silva, GA. 2011. Advances in Glomeromycota taxonomy and classification. IMA Fungus. 2, 191199.

Oehl, F., Laczko, E., Bogenrieder, A., Stahr, K., Bösch, R., van der Heijden, M., Sieverding, E. 2010. Soil type and land use intensity determines the composition of arbuscular mycorrhizal fungal communities. Soil Biol. Biochem. 42, 724-738. 
Oehl, F., Sieverding, E., Ineichen, K., Ris, E.A., Boller, T., Wiemken, A. 2005. Community structure of arbuscular mycorrhizal fungi at different soil depths in extensively and intensively managed agroecosystems. New Phytol. 165, 273-283.

Oehl, F., Sieverding, E., Mader, P., Dubois, D., Ineichen, K., Boller, T., Wiemken, A. 2004. Impact of long-term conventional and organic farming on the diversity of arbuscular mycorrhizal fungi. Oecologia. 138, 574-583.

Oehl, F., Sieverding, E., Ineichen, K., Mader, P., Boller, T., Wiemken, A. 2003. Impact of land use intensity on the species diversity of arbuscular mycorrhizal fungi in agroecosystems of Central Europe. Appl. Environ. Microbiol. 69, 2816-2824.

Öpik, M., Davinson, J., Moora, M., Zobel, M. 2014. DNA-based detection and identification of Glomeromycota: the virtual taxonomy of environmental sequences. Bot. 92, 135-147.

Öpik, M., Moora, M., Liira, J., Zobel, M. 2006. Composition of root-colonizing arbuscular mycorrhizal fungal communities in different ecosystems around the globe. J. Ecol. 94, 778-790.

Pagano, M.C., Zandavalli, R.B., Araújo, F.S. 2013. Biodiversity of arbuscular mycorrhizas in three vegetational types from the semiarid of Ceará State, Brazil. Appl. Soil Ecol. 67, 37-46.

Pereira, C.M.R., Silva, D.K.A., Ferreira, A.C.A., Goto, B.T., Maia, L.C. 2014. Diversity of arbuscular mycorrhizal fungi in Atlantic forest areas under different land uses. Agric. Ecosystem Environ. $185,245-252$.

Picone, C. 2000. Diversity and abundance of arbuscular mycorrhizal fungus spores in Tropical Forest and Pasture. Biotropica. 32, 734-750.

Pielou, E.C. 1975. Ecological Diversity. Wiley, New York, $165 \mathrm{p}$.
Pringle, A., Bever, J.D. 2002. Divergent phenologies may facilitate the coexistence of arbuscular mycorrhizal fungi in a North Carolina Grassland. Am. J. Bot. 89, 1439-1446.

Redecker, D., Morton, J.B., Bruns, T.D. 2000. Ancestral lineages of arbuscular mycorrhizal fungi (Glomales). Mol. Phylogenet. Evol. 14, 276-284.

Robinson-Boyer, L., Grzyb, I., Jeffries, P. 2009. Shifting the balance from qualitative to quantitative analysis of arbuscular mycorrhizal communities in field soils. Fungal Ecol. 2, 1-9.

Roldán, A., Salinas-García, J.R., Alguacil, M.M., Caravaca, F. 2007. Soil sustainability indicators following conservation tillage practices under subtropical maize and bean crops. Soil Till. Res. 93, 273-282.

Russell, J., Bulman, S. 2005. The liverwort Marchantia foliacea forms a specialized symbiosis with arbuscular mycorrhizal fungi in the genus Glomus. New Phytol. 165, 567-579.

Saito, K., Suyama, Y., Sato, S., Sugawara, K. 2004. Defoliation effects on the community structure of arbuscular mycorrhizal fungi base don 18SrDNA sequences. Mycorrhiza. 14, 363-373.

Säle, V., Aguilera, P., Laczko, E., Mäder, P., Berner, A., Zihlman, V., van der Heijden, M.G.A., Oehl, F. 2015. Impact of conservation tillage and organic farming on the diversity of arbuscular mycorrhizal fungi. Soil Biol. Biochem. 84, 38-52.

Sanders, I.R. 2004. Plant and arbuscular mycorrhizal fungal diversity- are we looking at the relevant levels of diversity and are we using the right techniques? New Phytol. 164, 415-418.

Sasvári, Z., Posta, K. 2010. Effect of different plant densities on the diversity of arbuscular mycorrhizal fungi community in a long-term maize monocrop system. Spain J. Agric. Res. (S1), S123S130. 
Schenck, N.C., Kinloch, R.A. 1980. Incidence of mycorrhizal fungi on six field crops in monoculture on a newly cleared woodland site. Mycologia. 72, 445-455.

Schenck, N.C., Pérez, Y. 1990. Manual for the identification of VA mycorrhizal fungi. Synergistic Publ., $3^{\text {rd }}$ edition, Gainesville, Florida, USA, 286 p.

Schüssler, A., Schwarzott, D., Walker, C. 2001. A new fungal phylum, the Glomeromycota: phylogeny and evolution. Mycol. Res. 105, 1413-1421.

Shannon, C.E., Weaver, W. 1949. The mathematical theory of communication. University of Illinois Press, Urbana, $28 \mathrm{p}$.

Sieverding, E., da Silva, G.A., Berndt, R., Oehl, F. 2014. Rhizoglomus, a new genus of the Glomeraceae. Mycotaxon. 129, 373-386.

Sieverding, E., Oehl, F. 2006. Revision of Entrophospora and description of Kuklospora and Intraspo$r a$, two new genera in the arbuscular mycorrhizal Glomeromycetes. J. Appl. Bot. Food Qual. 80, 69-81.

Sieverding, E., Oehl, F. 2005. Are arbuscular mycorrhizal fungal species invasive - derived from our knowledge about their distribution in different ecosystems? BCPC Symposium Proc. 81, 197202.

Sieverding, E. 1991. Vesicular-Arbuscular Mycorrhiza Management in Tropical Agrosystems. GTZ, Eschborn, Germany, 371 p.

Simon, L., Lalonde, M., Bruns, T.D. 1992. Specific amplification of $18 \mathrm{~S}$ fungal ribosomal genes from VA endomycorrhizal fungi colonizing roots. Appl. Environ. Microbiol. 58, 291-295.

Siqueira, J.O., Colozzi-Filho, A., Oliveira, E. 1989. Ocorrencia de micorrizas vesicular-arbusculares em agro e ecossistemas naturais do estado de Minas Gerais. Pesq. Agropec. Bras. 24, 14991506.
Siqueira, J.O., Hubbell, D.H., Mahmud, A.W. 1984. Effect of liming on spore germination, germ tube growth and root colonization by vesicular-arbuscular mycorrhizal fungi. Plant Soil. 76, 115-124.

Silva, D.K.A., Goto, B.T., Oehl, F., da Silva, G.A., Nobre, C.P., Pereira, C.M.R., de Mello, C.M.A., de Assis, D.M., Marinho, F., da Silva, I.R., de Pontes, J.S., Jobim, K., Cardoso Vieira, L., Ferreira de Sousa, N.M., Araújo de Lima, R.A., Maia, L.C. 2014. Arbuscular mycorrhizal fungi: new records in Northeast of Brazil. Bol. Mus. Biol. Mello Leitao. 36, :35-50.

Snoeck, D., Abolo, D., Jagoret, P. 2010. Temporal changes in VAM fungi in the cocoa agroforestry systems of Central Cameroon. Agrofor. Syst. 78, 323-328.

Soka, G., Ritchie, M. 2015. Arbuscular mycorrhizal symbiosis, ecosystem processes and environmental changes in tropical soils. Appl. Ecol. Environ. Res. 13, 229-245.

Souza, R.G., Goto, B.T., Silva, D.K.A., Silva, F.S.B., Sampaio, E.V.S.B., Maia, L.C. 2010. The role of arbuscular mycorrhizal fungi and cattle manure in the establishment of Tocoyena selloana Schum. in mined dune areas. European J. Soil Biol. 46, 237-242.

Sýkorová, Z., Ineichen, K., Wiemken, A., Redecker, D. 2007. The cultivation bias: different communities of arbuscular mycorrhizal fungi detected in roots from the field, from bait plants transplanted to the field, and from a greenhouse trap experiment. Mycorrhiza. 18, 1-14.

Tamuli, P., Boruah, P. 2002. VAM association of agar wood tree in Jorhat district of the Brahmaputra valley. Indian Forester, 128, 991-994.

Tchabi, A., Coyne, D., Hountondji, F., Lawouin, L., Wiemken, A., Oehl, F. 2008. Arbuscular mycorrhizal fungal communities in sub-Saharan savannas of Benin, West Africa, as affected by agricultural land use intensity and ecological zone. Mycorrhiza. 18, 181-195. 
Turrini, A., Giovannetti, M. 2012. Arbuscular mycorrhizal fungi in national parks, nature reserves and protected areas worldwide: a strategic perspective for their in situ conservation. Mycorrhiza. 22, 8197.

Urcoviche, R.C., Castelli, M., Toesca Gimenes, R.M., Alberton, O. 2014. Spore density and diversity of arbuscular mycorrhizal fungi in medicinal and seasoning plants. African J. Agric. Res. 9, 12441251.

van der Heijden, M.G.A., Streitwolf-Engel, R., Riedl, R., Siegrist, S., Neudecker, A., Ineichen, K., Boller, T., Wiemken, A., Sanders, I.R. 2006. The mycorrhizal contribution to plant productivity, plant nutrition and soil structure in experimental grassland. New Phytol. 172, 739-752.

van der Heidjen, M., Klironomos, J.N., Ursic, M., Moutoglis, P., Streitwolf-Engel, R., Boller, T., Wiemken, A., Sanders, I.R. 1998. Mycorrhizal fungal diversity determines plant biodiversity, ecosystem variability and productivity. Nature. 396, 69-72.

Vestberg, M., Saari, K., Kukkonen, S., Hurme, T. 2005. Mycotrophy of crops in rotation and soil amendment with peat influence the abundance and effectiveness of indigenous arbuscular mycorrhizal fungi in field soil. Mycorrhiza. 15, 447-458.

Vyas, D., Gupta, R.K. 2014. Effect of edaphic factors on the diversity of VAM fungi. Tropical Plant Res. 1, 14-25.
Wetzel, K., Silva, G.A., Matczinski, U., Oehl, F., Fester, T. 2014. Superior differentiation of arbuscular mycorrhizal fungal communities from till and no-till plots by morphological spore identification when compared to T-RFLP. Soil Biol. Biochem. $72,88-96$.

Wu, B., Hogetsu, T., Isobe, K., Ishii, R. 2007. Community structure of arbuscular mycorrhizal fungi in a primary successional volcanic desert on the southeast slope of Mount Fuji. Mycorrhiza. 17, 495-506.

Wubet, T., Weiss, M., Kottke, I., Teketay, D., Oberwinkler, F. 2004. Molecular diversity of arbuscular mycorrhizal fungi in Prunus africana an endangered medicinal tree species in dry Afromontane forests of Ethiopia. New Phytol. 161, 517-528.

Yang, F.Y., Li, G.Z., Zhang, D.E., Christie, P., Li, X.L., Gai, J.P. 2010. Geographical and plant genotype effects on the formation of arbuscular mycorrhizal in Avena sativa and Avena nuda at different soil depths. Biol. Fertil. Soils. 46, 435-443.

Zak, J.C., Willig, M.R. 2004. Análisis e interpretación de los patrones de biodiversidad de hongos. En: G.M. Mueller, G.F. Bills, M.S. Foster (eds). Biodiversidad de hongos: inventario y monitoreo de los métodos. Elsevier Academic Press., Burlington, Massachusetts, pp: 59-76. 